\section{Effects of Iron Source on Iron Chlorosis and Exserohilum Leaf Spot Severity in Wodyetia bifurcata}

\author{
Timothy K. Broschat and Monica L. Elliott \\ University of Florida, Fort Lauderdale Research and Education Center, 3205 \\ College Avenue, Fort Lauderdale, FL 33314
}

Additional index words. palm, foxtail palm, ferrous sulfate, ferrous ammonium sulfate, ferric citrate, FeEDDHA, FeEDTA, FeHEDTA, FeDPTA, iron glucoheptonate, chelate

\begin{abstract}
Foxtail palms (Wodyetia bifurcata Irvine) were grown in 6.2-L containers using a 3 calcitic limestone gravel : 2 coir dust (by volume) substrate to induce Fe chlorosis. Plants were treated initially and 2 and 4 months later with soil applications of FeDTPA, FeEDDHA, FeEDTA+FeHEDTA on vermiculite, FeEDTA+FeDTPA on clay, ferric citrate, ferrous ammonium sulfate, ferrous sulfate, ferrous sulfate+sulfur, or iron glucoheptonate at a rate of $0.2 \mathrm{~g} \mathrm{Fe} /$ container. Similar plants were treated initially and 2 and 4 months later with foliar sprays of FeDTPA, FeEDDHA, ferric citrate, ferrous sulfate, or iron glucoheptonate at a rate of $0.8 \mathrm{~g} \mathrm{Fe} / \mathrm{L}$. After 6 months, palms receiving soil applications of FeEDDHA, FeEDTA+FeHEDTA on vermiculite, FeDTPA, or FeEDTA+FeDTPA on clay had significantly less chlorosis than plants receiving other soil-applied Fe fertilizers or untreated control plants. Palms treated with foliar Fe fertilizers had chlorosis ratings similar to untreated control plants. Palms with the most severe Fe chlorosis also had the highest levels of leaf spot disease caused by Exserohilum rostratum (Drechs.) K.J. Leonard \& E.G. Suggs. Neither chlorosis severity nor leaf spot severity was correlated with total leaf Fe concentration.
\end{abstract}

Iron chlorosis is a widespread, and often difficult to correct, nutritional disorder (Korcak, 1987; Wallace and Lunt, 1960). Alkaline soil $\mathrm{pH}$ tends to accentuate chlorosis problems and under these conditions, soil applications of iron sulfate are often ineffective in correcting this disorder (Murphy and Walsh, 1972). Iron chelates such as FeEDDHA have been shown to be highly effective in correcting $\mathrm{Fe}$ chlorosis in a wide range of horticultural plants growing in alkaline soils (Martens and Westermann, 1991). Foliar fertilization with Fe fertilizers also has been used to correct $\mathrm{Fe}$ chlorosis in some crops where high soil $\mathrm{pH}$ or other environmental factors may reduce root uptake of soil-applied Fe (Murphy and Walsh, 1972; Swietlik and Faust, 1984). The authors are unaware of any published studies on the relative effectiveness of various Fe fertilizers in correcting $\mathrm{Fe}$ chlorosis in palms.

The foxtail palm (Wodyetia bifurcata) is native to northern Queensland, Australia, but was introduced into southern Florida in the mid-1980s, where it has been widely planted in landscapes. Since its introduction, we have observed that this species is highly susceptible to $\mathrm{pH}$-related $\mathrm{Fe}$ chlorosis. Iron chlorosis in foxtail palms is variable in its symptomology. Leaflets of new leaves of mildly Fe-deficient palms show a diffuse mottled interveinal chlorosis that increases in severity towards the tip of each leaflet. As the deficiency becomes more severe, the diffuse mottled interveinal

Received for publication 25 Aug. 2003. Accepted for publication 28 June 2004. Florida Agricultural Experiment Station journal series R-09723. The authors wish to thank Susan Thor and Anita Durden for their assistance in this project. chlorosis is gradually replaced by a more general diffuse Interveinal chlorosis, with green areas restricted largely to the major veins and the basal portion of the leaflet. Severely Fedeficient new leaves are uniformly light yellow and are noticeably smaller in size than mildly or moderately deficient leaves.

In a preliminary experiment evaluating the effectiveness of various $\mathrm{Fe}$ fertilizers in correcting Fe chlorosis in foxtail palm growing in a calcareous substrate, we noticed that chlorotic palms were much more severely affected by exserohilum leaf spot than palms with healthy dark green foliage. The purpose of this study was to evaluate the effectiveness of several commercially available Fe fertilizers in correcting $\mathrm{Fe}$ chlorosis and to determine the relationships between chlorosis severity, Fe source, and exserohilum leaf spot severity in foxtail palm.

\section{Materials and Methods}

Experiment 1. On 28 May 2000 the roots of immature foxtail palms growing in 2.8-L containers were washed free of potting substrate prior to transplanting into 6.2-L plastic containers using a 3 calcitic limestone gravel $(0.5$ to $1.5 \mathrm{~cm}): 2$ coir dust (by volume) substrate to induce Fe chlorosis. This substrate had a $\mathrm{pH}$ of 7.3. Plants were fertilized with Osmocote $13 \mathrm{~N}-5.6 \mathrm{P}-10.8 \mathrm{~K}$ at a rate of 30 $\mathrm{g} /$ container at the time of planting and every six months thereafter. Plants were grown in a fabric-covered shadehouse that provided a maximum photosynthetic photon flux of 900 $\mu \mathrm{mol} \cdot \mathrm{m}^{-2} \cdot \mathrm{s}^{-1}$ and received about $2 \mathrm{~cm}$ of water daily from overhead irrigation plus natural rainfall of about $150 \mathrm{~cm}$ annually. This ir- rigation water had a $\mathrm{pH}$ of 7.9 and contained $0.01 \mu \mathrm{g} \mathrm{Fe} / \mathrm{mL}$. On 3 Oct. 2001, Fe fertilizers were applied to the soil at a rate of $0.2 \mathrm{~g} \mathrm{Fe} /$ container or no $\mathrm{Fe}$ fertilizer, with 10 replicate plants per treatment. Iron fertilizer treatments were reapplied 2 and 4 months after the initial application. Iron sources used were FeDTPA, FeEDDHA, FeEDTA plus FeHEDTA on vermiculite (Hampshire Fe), ferric citrate, ferrous ammonium sulfate, ferrous sulfate, ferrous sulfate plus sulfur (DisperSul Fe), and iron glucoheptonate. Trade names, Fe contents, application rates, and manufacturers for these materials are listed in Table 1.

Ten replicate similarly grown palms were also treated with foliar sprays containing soluble Fe fertilizers at a rate of $0.8 \mathrm{~g} \mathrm{Fe} / \mathrm{L}$ or no $\mathrm{Fe}$ fertilizer in the spray (control). A surfactant (Wet All; Sun Chemical, Arcadia, Fla.) was added to all foliar sprays at a rate of $2 \mathrm{~mL} \cdot \mathrm{L}^{-1}$. Applications were made in the morning between 0800 and $1000 \mathrm{HR}$, and the plants did not receive irrigation until the following morning. Foliar sprays were applied up to the point of runoff on 4 Oct. 2002 and again at 2 and 4 months after that date. Products used as foliar sprays were FeDTPA, FeEDDHA, ferric citrate, ferrous ammonium sulfate, ferrous sulfate, and iron glucoheptonate. All plants within each fertilization method block were arranged in a completely randomized design.

Six months following the initial treatments the youngest fully expanded leaf on each palm was rated subjectively for chlorosis severity using a scale of 1 to 5 , with $1=$ severe chlorosis (completely white foliage), $3=$ moderate chlorosis (about $50 \%$ green), and $5=$ no chlorosis. Since Fe chlorosis in foxtail palms was extremely nonuniform within a palm leaf and leaflet and many leaves had extensive necrosis due to leaf spot disease, neither chlorophyll analysis nor SPAD meter readings could be used to quantify chlorosis severity. Using the same leaf, the percentage of leaf area covered by leaf spot lesions was also subjectively estimated for each plant.

Samples consisting of the two central leaflets on the youngest fully expanded leaf of each palm were collected for leaf $\mathrm{Fe}$ analysis. Leaf samples were pooled into three composite samples from three palms each, with one sample composed of leaflets from four palms. Since palm leaves are produced at a rate of about one per month and two months had transpired since the last foliar treatment, leaf samples were not washed before processing for analysis. Leaf samples were dried at 65 ${ }^{\circ} \mathrm{C}$, ground, and digested using a modified Kjeldahl procedure (Hach, et al., 1987). Iron concentrations were determined by atomic absorption spectroscopy, with data expressed as total milligrams of Fe per kilogram of leaf dry weight.

Diseased leaf samples were obtained for pathogen isolation. Symptomatic tissue with leaf spots and necrosis was washed under tap water, surface sterilized for $1 \mathrm{~min}$ with $0.5 \%$ sodium hypochlorite, blotted dry on sterile filter paper, and placed on 1/5 strength potato dextrose agar (Difco). Dominant fungal colonies recovered were purified and then transferred 
Table 1. Iron fertilizer materials used in the treatment of Fe chlorosis on foxtail palm growing in a calcareous substrate.

\begin{tabular}{|c|c|c|c|c|c|}
\hline $\begin{array}{l}\mathrm{Fe} \\
\text { source }\end{array}$ & $\begin{array}{l}\text { Trade } \\
\text { name }\end{array}$ & $\begin{array}{l}\mathrm{Fe} \\
(\%)\end{array}$ & $\begin{array}{l}\text { Soil application } \\
\text { rate (g/pot) }\end{array}$ & $\begin{array}{l}\text { Foliar application } \\
\text { rate }\left(\mathrm{g} \cdot \mathrm{L}^{-1}\right)\end{array}$ & Manufacturer \\
\hline FeDTPA & Sequestrene 330 & 10.0 & 2.0 & 8.0 & Becker-Underwood, Ames, Iowa \\
\hline Fe EDDHA & Sequestrene 138 & 6.0 & 3.34 & 13.3 & Becker-Underwood, Ames, Iowa \\
\hline FeEDTA + FeDTPA on clay & Trachelene Fe & 5.0 & 4.0 & --- & Traylor Chemical \& Supply, Orlando, Fla. \\
\hline FeEDTA + FeHEDTA on vermiculite & Hampshire Fe & 5.0 & 4.0 & --- & Hampshire Chemical Co., Nashua, N.H. \\
\hline Ferric citrate & & 16.0 & 1.26 & 5.0 & Fisher Chemical, Fair Lawn, N.J. \\
\hline Ferrous ammonium sulfate & & 14.0 & 1.43 & 5.7 & Sigma Chemical, St. Louis, Mo. \\
\hline Ferrous sulfate & & 20.0 & 0.98 & 3.8 & QC Corp., Cape Girardeau, Mo. \\
\hline Ferrous sulfate + sulfur & DisperSul Fe & 5.0 & 4.0 & --- & Martin Resources, Kilgore, Texas \\
\hline Iron glucoheptonate & Accellerate Iron & 5.0 & 4.0 & 16.0 & Florikan ESA, Sarasota, Fla. \\
\hline
\end{tabular}

to V-8 juice agar (per liter: $200 \mathrm{~mL} \mathrm{V-8} \mathrm{juice,}$ $4.0 \mathrm{~g} \mathrm{CaCO}_{3}$, and $15.0 \mathrm{~g}$ Bacto agar). These plates were incubated at room temperature under $12 \mathrm{~h}$ light from fluorescent bulbs to produce conidia for identification purposes (Uchida, 2004).

Data were analyzed by analysis of variance, with mean separation by the Waller-Duncan $\mathrm{k}$ ratio method, or by regression analysis (SAS, SAS Inst., Cary, N.C.).

Experiment 2. A second similar experiment was initiated on 31 July 2002, with Fe treatments applied on 31 Jan. 2003 and every 2 months thereafter for 4 months. Treatments consisted only of soil-applied Fe fertilizers, since foliar applied $\mathrm{Fe}$ was found to be ineffective in Expt. 1. Treatments were control (no Fe fertilizer), FeDTPA, FeEDDHA, FeEDTA plus FeDTPA on clay (Trachelene Fe), ferrous sulfate, and FeEDTA plus FeHEDTA on vermiculite (Hampshire Fe). Application rates and sources for these products are listed in Table 1. Palm chlorosis and leaf spot disease severity were rated as in Expt. 1 after 6 months, and leaves were similarly sampled for $\mathrm{Fe}$ analysis and pathogen isolation.

\section{Results and Discussion}

Iron fertilizers differed greatly in their ability to correct $\mathrm{Fe}$ chlorosis in foxtail palms growing in a calcareous substrate. In Expt. 1, soil applications of FeEDDHA, FeEDTA plus FeHEDTA, and FeDTPA resulted in significantly less chlorosis (higher ratings) than the untreated controls or other soil-applied treatments (Table 2). In Expt. 2, these three fertilizers and a fourth fertilizer, FeEDTA plus FeDTPA, provided results similar to Expt. 1 (Table 4). Of these four fertilizers, FeEDDHA resulted in the least chlorosis in both experiments. Foliar applications of water-soluble $\mathrm{Fe}$ fertilizers to foxtail palms did not reduce chlorosis when compared to untreated control plants (Table 3).

The leaf spot disease observed on chlorotic palms began as small, black spots (about $2 \mathrm{~mm}$ in diameter) and expanded into large circular and elliptical lesions with necrotic centers. The only fungal pathogen isolated from the necrotic lesions produced conidia (asexual spores) with rounded ends and a hilum proturberance. The primarily ellipsoidal-shaped spores had 7 to 9 cells and were $65 \pm 8 \mu \mathrm{m}$ long (range of 54 to $85 \mu \mathrm{m}$ ) by $15 \pm 1 \mu \mathrm{m}$ wide (range of 12 to 17 $\mu \mathrm{m})$. This description most closely matched that of Exserohilum rostratum (Sivanesan 1987), a pathogen known to cause leaf spots of numer- ous palms in Florida (Chase, 1982).

Iron source and application method also affected the percentage of leaf area covered with exserohilum leaf spot lesions. In Expt. 1, soil applications of FeEDDHA, FeEDTA plus FeHEDTA, and FeDTPA resulted in significantly less disease than all other treatments (Table 2). These are the same treatments that significantly reduced $\mathrm{Fe}$ chlorosis. In Expt. 2, only the soil-applied FeEDDHA treatment resulted in lower disease ratings than the untreated control, and this treatment was also

the most effective in improving $\mathrm{Fe}$ chlorosis in this experiment (Table 4). The correlation between chlorosis severity and exserohilum leaf spot severity on foxtail palms was highly significant $(r=-0.65, P<0.0001$ for Expt. 1 and $r=-0.88, P<0.0001$ for Expt. 2) for soil-applied Fe sources. None of the foliarapplied $\mathrm{Fe}$ sources had lower disease ratings than the control (Table 3). The correlation between chlorosis and leaf spot severity was not significant for foliar-applied Fe sources, since all of the treatments resulted in equally

Table 2. Iron chlorosis and exserohilum leaf spot severity of the youngest fully expanded leaf of foxtail palms treated with various soil-applied Fe fertilizers; Expt. 1.

\begin{tabular}{lccc}
\hline Fe & $\begin{array}{c}\text { Chlorosis } \\
\text { rating }\end{array}$ & $\begin{array}{c}\text { Disease } \\
\text { coverage }^{\mathrm{y}} \\
(\%)\end{array}$ & $\begin{array}{c}\text { Leaf } \\
\text { total Fe } \\
\left(\mathrm{mg}^{\mathrm{k}} \mathrm{kg}^{-1}\right)\end{array}$ \\
\hline Control & $2.4 \mathrm{~b}^{\mathrm{x}}$ & $56.5 \mathrm{ab}$ & $184.3 \mathrm{~d}$ \\
FeDTPA & $3.7 \mathrm{a}$ & $7.0 \mathrm{c}$ & $134.3 \mathrm{f}$ \\
FeEDDHA & $4.0 \mathrm{a}$ & $2.2 \mathrm{c}$ & $215.3 \mathrm{a}$ \\
Fe EDTA + FeHEDTA & $3.8 \mathrm{a}$ & $3.9 \mathrm{c}$ & $140.7 \mathrm{e}$ \\
Ferric citrate & $2.1 \mathrm{~b}$ & $75.8 \mathrm{a}$ & $184.0 \mathrm{~d}$ \\
Ferrous ammonium sulfate & $2.2 \mathrm{~b}$ & $38.2 \mathrm{~b}$ & $140.7 \mathrm{e}$ \\
Ferrous sulfate & $2.2 \mathrm{~b}$ & $45.0 \mathrm{~b}$ & $189.7 \mathrm{c}$ \\
Ferrous sulfate + sulfur & $2.3 \mathrm{~b}$ & $49.9 \mathrm{~b}$ & $195.0 \mathrm{~b}$ \\
Iron glucoheptonate & $2.3 \mathrm{~b}$ & $59.8 \mathrm{ab}$ & $142.3 \mathrm{e}$ \\
\hline
\end{tabular}

${ }^{2}$ Percentage of leaf surface area covered by leaf spot lesions.

${ }^{\mathrm{y}}$ Rating scale: 1 = severe chlorosis, 3 = moderate chlorosis, $5=$ no chlorosis.

${ }^{\mathrm{x}}$ Mean separation within columns by the Waller-Duncan k ratio method $(P=0.05)$.

Table 3. Iron chlorosis and exserohilum leaf spot severity of the youngest fully expanded leaf of foxtail palms treated with various foliar-applied Fe fertilizers; Expt. 1.

\begin{tabular}{lccc}
\hline $\begin{array}{l}\text { Fe } \\
\text { source }\end{array}$ & $\begin{array}{c}\text { Chlorosis } \\
\text { rating }^{y}\end{array}$ & $\begin{array}{c}\text { Disease } \\
\text { coverage }^{z} \\
(\%)\end{array}$ & $\begin{array}{c}\text { Leaf } \\
\text { total Fe } \\
\left(\mathrm{mg}^{\mathrm{k}} \mathrm{kg}^{-1}\right)\end{array}$ \\
\hline Control & $2.4 \mathrm{a}^{\mathrm{x}}$ & $56.5 \mathrm{a}$ & $184.3 \mathrm{f}$ \\
FeDTPA & $2.3 \mathrm{a}$ & $44.4 \mathrm{a}$ & $154.0 \mathrm{~g}$ \\
FeEDDHA & $2.3 \mathrm{a}$ & $41.5 \mathrm{a}$ & $309.0 \mathrm{c}$ \\
Ferric citrate & $2.3 \mathrm{a}$ & $52.5 \mathrm{a}$ & $473.0 \mathrm{a}$ \\
Ferrous ammonium sulfate & $2.0 \mathrm{a}$ & $37.8 \mathrm{a}$ & $211.0 \mathrm{e}$ \\
Ferrous sulfate & $2.3 \mathrm{a}$ & $60.8 \mathrm{a}$ & $446.7 \mathrm{~b}$ \\
Iron glucoheptonate & $2.3 \mathrm{a}$ & $59.8 \mathrm{a}$ & $294.0 \mathrm{~d}$ \\
\hline
\end{tabular}

${ }^{\mathrm{z}}$ Percentage of leaf surface area covered by leaf spot lesions.

${ }^{\mathrm{y}}$ Rating scale: 1 = severe chlorosis, 3 = moderate chlorosis, $5=$ no chlorosis.

${ }^{x}$ Mean separation within columns by the Waller-Duncan k ratio method $(P=0.05)$.

Table 4. Iron chlorosis and exserohilum leaf spot severity of the youngest fully expanded leaf of foxtail palms treated with various soil-applied Fe fertilizers; Expt. 2.

\begin{tabular}{lccc}
\hline Fe & $\begin{array}{c}\text { Chlorosis } \\
\text { rating }\end{array}$ & $\begin{array}{c}\text { Disease } \\
\text { coverage } \\
(\%)\end{array}$ & $\begin{array}{c}\text { Leaf } \\
\text { total Fe } \\
\left(\mathrm{mg}^{\mathrm{y}} \cdot \mathrm{kg}^{-1}\right)\end{array}$ \\
\hline Control & $1.3 \mathrm{c}^{\mathrm{x}}$ & $74.6 \mathrm{a}$ & $165.0 \mathrm{ab}$ \\
FeDTPA & $3.2 \mathrm{~b}$ & $63.3 \mathrm{ab}$ & $183.7 \mathrm{a}$ \\
FeEDDHA & $4.4 \mathrm{a}$ & $21.5 \mathrm{~b}$ & $155.0 \mathrm{abc}$ \\
FeEDTA + FeDTPA & $3.5 \mathrm{~b}$ & $50.0 \mathrm{ab}$ & $117.0 \mathrm{bc}$ \\
Fe EDTA + FeHEDTA & $3.5 \mathrm{~b}$ & $40.3 \mathrm{ab}$ & $114.6 \mathrm{c}$ \\
Ferrous sulfate & $1.5 \mathrm{c}$ & $73.8 \mathrm{a}$ & $119.0 \mathrm{bc}$ \\
\hline
\end{tabular}

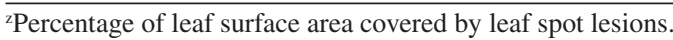

${ }^{y}$ Rating scale: 1 = severe chlorosis, 3 = moderate chlorosis, $5=$ no chlorosis.

${ }^{\mathrm{x}}$ Mean separation within columns by the Waller-Duncan $\mathrm{k}$ ratio method $(P=0.05)$. 
chlorotic plants with similarly high disease severity ratings.

A previous study examining effects of foliar micronutrient spray applications on E. rostratum leaf spot of Dypsis lutescens (areca palm) demonstrated an inconsistent direct effect of FeDPTA on disease control (Chase and Poole, 1984). They also observed that this iron chelate could cause significant plant damage, but no plant damage could be attributed to foliar application of iron sources in our study.

Soil applications of iron chelates have been correlated with a reduction in disease development for both foliar and soilborne diseases (Barash et al., 1993). This has been especially true for plants growing in calcareous soils (Barash et al., 1988; Goldweber 1975). While the exact mechanism by which iron chelates suppress disease development is unknown, it is probably dependent on the host/pathogen system. The general rule for plants is that iron deficiency usually increases disease severity (Barash et al., 1993). Studies examining fungal spores of aerial pathogens have suggested that iron inhibits germination and appressorium formation, the first steps in the disease process (Barash et al., 1993).

Leaf total $\mathrm{Fe}$ concentration was highly variable among treatments in both experiments, and there was no correlation between leaf Fe concentration and chlorosis or disease severity (Tables 2 through 4). Other studies have similarly found $\mathrm{Fe}$ chlorosis to be poorly correlated with total leaf Fe concentration, or that plants with the highest $\mathrm{Fe}$ concentration also showed the most severe chlorosis (Chaney, 1984; Wallace, 1971).

In conclusion, the most effective Fe treatment for $\mathrm{Fe}$ chlorosis in foxtail palms was soil-applied FeEDDHA, followed by soil-applied FeEDTA plus FeHEDTA, FeEDTA plus FeDTPA, and FeDTPA. Exserohilum leaf spot disease severity was highly correlated with $\mathrm{Fe}$ chlorosis severity, and fertilization treatments that reduced $\mathrm{Fe}$ chlorosis also reduced the severity of this disease. However, total leaf Fe concentration was not related to either chlorosis severity nor to disease severity.

\section{Literature Cited}

Barash, I., S. Dori, H. Mor, and S. Manulis. 1993. Role of iron in fungal phytopathologies, p. 251-267 In: L.L. Barton and B.C. Hemming (eds.). Iron chelation in plants and soil microorganisms. Academic Press, San Diego.

Barash, I., R. Zion, J. Krikun, and A. Nachmias. 1988. Effect of iron status on verticillium wilt disease and on in-vitro production of siderophores by Verticillium dahliae. J. Plant Nutr. 11:893-905.

Chaney, R.L. 1984. Diagnostic practices to identify iron deficiency in higher plants. J. Plant Nutr. 9:47-67.

Chase, A.R. 1982. Dematiaceous leaf spots of Chrysalidocarpus lutescens and other palms in Florida. Plant Dis. 66:697-699.

Chase, A.R. and R.T. Poole. 1984. Influence of foliar applications of micronutrients and fungicides on foliar necrosis and leaf spot disease of Chrysalidocarpus lutescens. Plant Dis. 68:195-197.

Goldweber, S. 1975. The use of a chelated iron to restore normal vigor to verticillium wilt in- fected mango trees. Proc. Fla. State Hort. Soc. $88: 499-500$.

Hach, C.C., B.K. Bowen, A.B. Koplove, and S.V. Brayton. 1987. More powerful peroxide Kjeldahl digestion method. J. Assn. Off. Anal. Chem. 70:783-787.

Korcak, R.F. 1987. Iron deficiency chlorosis. Hort. Rev. 9:133-136.

Martens, D.C. and D.T. Westermann. 1991. Fertilizer applications for correcting micronutrient deficiencies, p. 549-592 In: J.J. Mortvedt, F.R. Cox, L.M. Shuman, and R.M. Welch (eds.). Micronutrients in agriculture. 2nd ed. Soil Sci. Soc. Amer., Madison, Wis.

Murphy, L.S. and L.M. Walsh. 1972. Correction of micronutrient deficiencies with fertilizers, $\mathrm{p}$. 347-387 In: J.J. Mortvedt, P.M. Giordano, and W.L. Lindsay (eds.). Micronutrients in agriculture. Soil Sci. Soc. Amer., Madison, Wis.

Sivanesan, A. 1987. Graminicolous species of $\mathrm{Bi}$ polaris, Curvularia, Dreschslera, Exserohilum and their teleomorphs. CAB Intl., Wallingford, U.K.

Swietlik, D. and M. Faust. 1984. Foliar nutrition of fruit crops. Hort. Rev. 6:287-355.

Uchida, J.Y. 2004. Bipolaris and exserohilum leaf spots. In: M.L. Elliott, T.K. Broschat, J.Y. Uchida, and G.W. Simone (eds.). Compendium of diseases and disorders of ornamental palms. Amer. Phytopathol. Soc. Press, St. Paul, Minn.

Wallace, A. 1971. Do chlorotic leaves contain more iron than green leaves? p. 194-195 In: A. Wallace (ed.). Regulation of the micronutrient status of plants by chelating agents and other factors. Edward Brothers, Ann Arbor, Mich.

Wallace, A. and O.R. Lunt. 1960. Iron chlorosis in horticultural plants, a review. Proc. Amer. Soc. Hort. Sci. 75:819-841. 